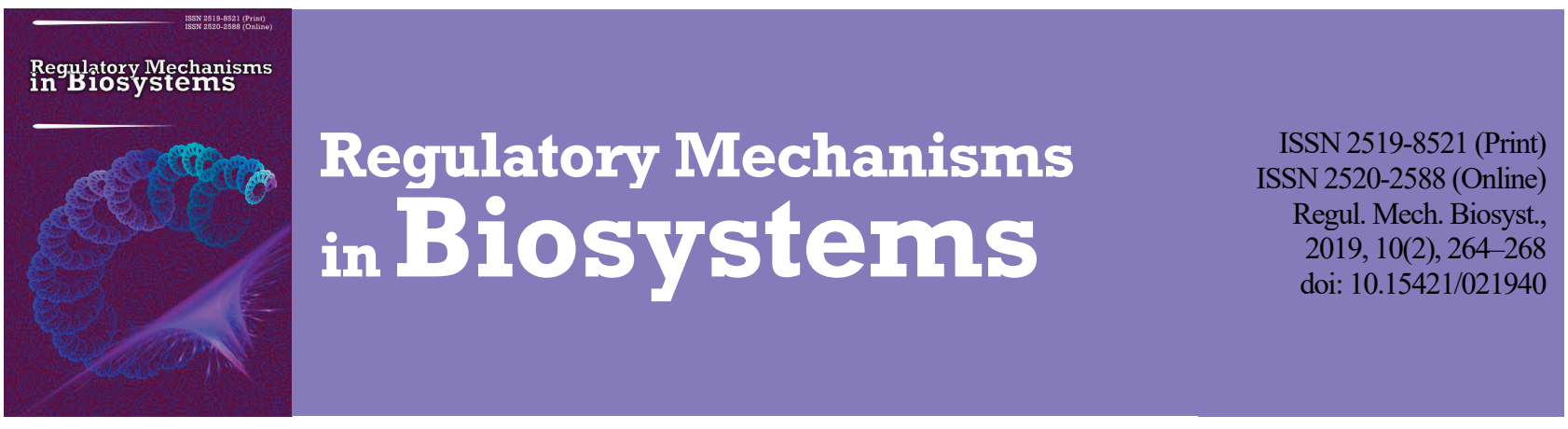

\title{
Agro-ecological cultivation, secondary metabolite characteristics and microbiological tests of lemon balm (Melissa officinalis) - the variety Citronella
}

\author{
I. Salamon*, M. V. Kryvtsova**, K. I. Trush**, A. I. Fandalyuk***, M. J. Spivak**** \\ *University of Prešov, Prešov, Slovakia \\ **Uzhhorod National University, Uzhhorod, Ukraine \\ ***Zakarpatian Institute of Agroindustrial Production, Velikaja Bakta, Ukraine \\ ****D. K. Zabolotny Institute of Microbiology and Virology of NAS of Ukraine, Kyiv, Ukraine
}

Article info

Received 10.04.2019

Received in revised form 06.05.2019

Accepted 07.05.2019

University of Prešov

17 Novembra st., 1, Prešov,

08116, Slovakia.

Tel.: +4-219-179-840-60

E-mail: ivan.salamon@unipo.sk

Uzhhorod National University,

Pidhirna st., 46,

Uzhhorod, 88000, Ukraine.

Tel.: +38-050-278-54-97.

E-mail: mary-

na.krivcova@gmail.com

Zakarpatian Institute

of Agroindustrial Production,

Svobody st., 1, Velikaja Bakta,

90252, Ukraine.

Tel.: +38-031-412-31-74

E-mail:insbakta@ukr.net

D. K. Zabolotny Institute of

Microbiology and Virology of NAS

of Ukraine, Zabolotnogo st., 154,

Kyiv, 03143, Ukraine.

Tel.: +38-044-526-23-79

E-mail:n.spivak@ukr.net

\begin{abstract}
Salamon, I., Kryvtsova, M. V., Trush, K. I., Fandalyuk, A. I., \& Spivak, M. J. (2019). Agro-ecological cultivation, secondary metabolite characteristics and microbiological tests of lemon balm (Melissa officinalis) - the variety Citronella. Regulatory Mechanisms in Biosystems, 10(2), 264-268. doi:10.15421/021940
\end{abstract}

Lemon balm (Melissa officinalis L.) is a native of the eastern Mediterranean region southward to Israel and Syria and eastward through the Crimea, the Caucasus, and Northern Iran to the Tien Shan and the Pamirs. It appears to have been naturalized in the Central Europe including the Carpathian Ukraine and Eastern Slovakia. The objective of this study was characterization of the chemical composition and antimicrobial activity of essential oils from Melissa officinalis L. variety Citronella in the conditions of cultivation in a lowland region of the Ukrainian Carpathians. Plant material, balm dry leaves and leafy tops of the shoots, were grown in a small-scale cultivation ground at the Zakarpatian Institute of Agroindustrial Production in Velikaja Bakta, Carpathian-Ukraine. The Citronella variety is used for herb production. Essential oil from balm parts (herb and leaves) was isolated by distillation with boiled water. Hydro-distillation lasted for 4 hours, sample weights were $10 \mathrm{~g}$ of dry drug matter. A modified Coocking \& Middleton distillation apparatus was used. Identification and evaluation of balm essential oil were carried out using the selected analytical method of HPLC-DAD analysis. The final balm extract was analyzed directly on a Dionex UltiMate 3000 system. The analysis of balm essential oil was carried out using a gas chromatograph Varian 3090, connected to a MS Saturn 2100T integrator. The sensitivity of microorganisms to plant extracts was determined by the disk diffusion test (with disk diameter of $6 \mathrm{~mm}$ ). The quantitative and qualitative characteristics of balm essential oil $(0.05-0.12 \%$ $\mathrm{v} / \mathrm{w})$ and its composition show very high content of $\alpha$-citrale (geranial) $(44 \%), \beta$-citrale (neral) $(29 \%)$ and citronellal $(9 \%)$. Rosmarinic acid can be extracted from leaves and its content equals up to $1.7 \pm 0.1 \%$. Composition of the natural substances depends on the balm taxon, origin, soil and climatic growing conditions, and methods of harvest and isolation and effective weed control which are used. Antibacterial effect of the oil showed low activity against all bacterial strains. Our results confirmed higher activity of EOs against Gram-positive bacteria than Gram-negative. The balm essential oil displayed antimitotic effect especially towards Candida glabrata clinical strain. Thus, studies have shown that Melissa officinalis variety of Citronella in the conditions of cultivation in the lowland region of Carpathian-Ukraine according to biochemical characteristics and microbiological properties corresponds to world analogues.

Keywords: essential oil; chemical composition; antimicrobial activity; aromatic plant.

\section{Introduction}

The name balm comes from the Greek balsamon meaning "balsam", an oily, fragrant resin. Since balm does not actually exude a balsam, it probably received its name from its fragrant aroma and its ability to soothe and calm the nerves. Balm has been known since antiquity for its medicinal qualities and for its use in bee-keeping (bees are particularly attracted to its pollen). The name Melissa of the genus of balms is the Greek word for bee (Lust, 2014).

Lemon balm is a perennial plant that is common in the Mediterranean area and the Near East but is also naturalized in some places in Central Europe (Macura et al., 2011; Gurčík et al., 2012; Doğan et al., 2013). Mostly it is cultivated as a culinary herb, but it also grows in fields and gardens in Crimea, Ivano-Frankivsk, Lvov regions and Carpathian Ukraine. Essential oil obtained from Melisa officinalis L. has shown antioxidant (Helmy, 2006; Ondrejovič et al., 2012; Safaeian et al., 2016; Couladis \& Koutsaviti, 2017), antibacterial (Rostami et al., 2012; Zazharskyi et al., 2019) and antitumour properties (De Sousa et al., 2004; Queiroz et al., 2014). Lemon balm is used in various branches of industry such as medicine, cosmetics and food.

The young shoots have a pleasant lemon aroma before budding. They are rich in vitamins, proteins, phytocides, microelements and other biologically active substances needed for the organism, especially after winter exhaustion. Lemon balm is used as a spicy herb in dry and fresh conditions. Fresh leaves can be put into any summer salads or vegetable soups. Dry leaves are used in the same meals in winter. Mixed with other spicy-aromatizing herbs, balm is very useful for preparing phytotea and stewed fruits (Babulka, 2005). Also, it could be added into homemade beer and kvass and also flavoured vinegar. Balm goes well with other herb spices in pickles, tinned foods, pickles of cucumber, tomatoes, food vegetable marrow, pepper, etc. In cookery, it is possible to sprinkle meat, or fish with powder from balm leaves as well as game some minutes before readiness. Lemon balm is a wonderful medical plant. It could be useful in treating all kinds of neuroses, stomach pain, problems in bowels that do not disappear under strict observance of keeping of diet, migraine and different headaches (Yarnell et al., 2013). 
Tea from balm removes shortness of breath, attack of tachycardia, pain in heart, at the same time slows down breathing and rhythm of heart systoles, reducing blood pressure. Oil and tincture are used for applying to affected areas and bathes at rheumatism pain. Balm is very useful in bee-keeping because it is a good honey-bearing plant. Bees readily inhabit hives on the inside of which balm syrup was rubbed and that is why balm is named bee-grass.

The objective of this paper was characterization of the chemical composition and antimicrobial activity of essential oils from M. officinalis, variety Citronella, in the conditions of cultivation in the lowland region of the Ukrainian Carpatians.

\section{Material and methods}

Plant material, balm dry leaves and leafy tops of the shoots, were taken from plants grown in a small-scale cultivation ground in the $\mathrm{Za}$ karpatian Institute of Agroindustrial Production in Velikaja Bakta, Carpathian-Ukraine. The Citronella variety is used for production of medicinal herbs. The variety has straight-standing, branch, slightly fluffy stem $0.7-0.8 \mathrm{~m}$ long. From the $4-5$ th years of vegetation the number of stems is 90 to 100 . Leaves are opposite to each other, long-oval form, serrated, very aromatic. The lower part of leaf is lighter in colour than the upper one, which is fluffed with short hair. The length of leaf is 50 or $70 \mathrm{~mm}$, the width ranges 30 to $50 \mathrm{~mm}$. Flowers have two white or yellowish small lips, collected in clusters with 5-10 flowers. Seeds are dark-blue and white, dotted, shining smooth nuts. The weight of 1000 seeds was $0.7-0.8 \mathrm{~g}$. Restoration of vegetation begins in late March or in early April and prolongs to 120 or 130 days in the first year and increases to 160 days in the following years. The number of days from restoration of vegetation to flowering fluctuates from 75 to 115 days. Flowering of the balm takes place from June to August and provides a long period for bees to collect honey. Seeds ripen from September to October. Balm is a drought- and frost-resistant, light-demanding herb. It does not depend on the soil type, but it grows better on loamy soils, rich with humus. It can grow in shade but in this case the yield is reduced. One plant can grow in the same place up to 5 years. In regard to varying soil-climatic conditions, the Western Ukraine Lowland provides heterogeneous conditions for variety of plant species, which are characterized by biodiversity and abundant gene pool material. This plain is also one of the most productive agricultural regions of Ukraine.

Balm powdered drug in amount of $1 \mathrm{~g}$ of the plant tissues was homogenized, $80 \mathrm{~mL}$ of ethanol $(50 \%) \mathrm{R}$ was added, boiled in a waterbath under reflux condenser for $30 \mathrm{~min}$. Then the substance was left to cool and filtered. The filter was rinsed with $10 \mathrm{~mL}$ of ethanol $(50 \% \mathrm{v} / \mathrm{v})$ $\mathrm{R}$. The filtrate were put into a volumetric flask and diluted to $100.0 \mathrm{~mL}$ using ethanol (50\%) R (Murarikova et al., 2015).

Essential oil from balm parts (herb and leaves) was isolated by distillation with boiled water. Hydro-distillation lasted for 4 hours, sample weights were $10 \mathrm{~g}$ of dry drug matter. The modified Coocking \& Middleton distillation apparatus was used. Identification and evaluation of the balm's essential oil were carried out using the selected analytical methods.

The analysis of the balm's essential oil was carried out using a Varian 3090 gas chromatograph connected to MS Saturn 2100T integrator. The following operating conditions were used: capillary column: RX5MS, $30 \mathrm{~m}$ x $0.250 \mathrm{~mm}$ i.d., film thickness: $0.25 \mu \mathrm{m}$, carrier gas: $\mathrm{He}_{2}$, adjusted to a flux of $1.5 \mathrm{~mL} / \mathrm{min}$, injection and FID-detector temperatures: $220^{\circ} \mathrm{C}$ respectively $250{ }^{\circ} \mathrm{C}$, a capacity of sample injection: $2 \mu \mathrm{L}$, MS-detector with automatic injector type 1177.

Components were identified by their GC retention times, and the obtained values were comparable to those mentioned in the literature (Ieri et al., 2017). Oil component standards for comparison were supplied by Extrasynthese, Merck, Fulka and Roth.

The final balm extract was analyzed directly on a Dionex UltiMate 3000 system. Stationary phase was Phenomenex Kinetex 100 A (C18, $5 \mu \mathrm{m}, 250 \mathrm{~mm} \times 4,6 \mathrm{~mm})$. Mobile phase $\mathrm{C}$ was water: $\mathrm{H}_{3} \mathrm{PO}_{4}-99.5$ : $0.5(\mathrm{v} / \mathrm{v})$, mobile phase D: methanol: $\mathrm{H}_{2} \mathrm{SO}_{4} 50: 50(\mathrm{v} / \mathrm{v})$, with flow equaling $1.0 \mathrm{~mL} / \mathrm{min}$, mobile phase gradient: $0 \mathrm{~min}$. $-100 \% \mathrm{C}, 5 \mathrm{~min}$. $100 \%$ C, 25 min. - 100\% D, 35. min. - 100\% D, 40 min. - 100\% C and temperature of thermostat was $30^{\circ} \mathrm{C}$. Detection wave length $\lambda=$
$340 \mathrm{~nm}$. Content of rosmarinic acid was determined by using the standard $(\geq 98 \%)$ from Merck.

The sensitivity of microorganisms to plant extracts was determined by the disk diffusion test (Balouiri et al., 2016). The bacterium inocula $100 \mu \mathrm{L}$ in the physiological solution were adjusted to the equivalent of 0.5 McFarland standard, and evenly spread on the surface of MullerHinton agar (incubated at $37 \pm 2{ }^{\circ} \mathrm{C}$ for 24 hours); yeasts - on SDA agar (incubated at $35 \pm 2{ }^{\circ} \mathrm{C}$ for 48 hours). Sterile filter paper disks $(6 \mathrm{~mm}$ in diameter) impregnated with $10 \mu \mathrm{L}$ of essential oil were placed on the dish plate previously inoculated with a microbial suspension. The diameters of the inhibition zones were measured in millimeters including the diameter of the disk. Each antimicrobial assay was performed at least three times. As test culture, we used the following microorganisms from the ATTC (American Type Culture Collection, USA) collection: Candida albicans ATCC 885-653, Staphylococcus aureus ATCC 25923, Escherichia coli ATCC 25922, Enterococcus faecalis ATCC 29212, Streptococcus pyogenes ATCC 19615. Also we used clinical strains of bacteria and yeast, which were isolated from the oral cavity of patients with periodontal disease. As negative control were used DMSO.

Data obtained were expressed as mean \pm standard deviation (SD) of three measurements. Tukey's test was applied for comparisons of the values; differences were considered significant at $\mathrm{P}<0.05$.

\section{Results}

Crop management practice of balm cultivation in the Ukrainian Carpathians. Balm seedlings grow in greenhouses or hotbeds. Soil mixture is prepared from turf earth, peat and humus in proportion 1:1:1. If there is no peat, the mixture is prepared from turf and humus in proportion 50:30. Sand in amount of $10-30 \mathrm{~kg} / \mathrm{m}^{2}$ or chopped straw, or 2$10 \mathrm{~kg}$ of ash can be added per one square $\mathrm{m}$. For improving the structure and aeration of the ground it is reasonable to add zeolite, but no more than the one fourth part. In this case, the germinating power of the seeds increases, the developing of root system and the upper elevated part of herbs improves. To improve the nutritious characteristic of the soil mixture, mineral fertilizers are added: superphosphate $50 \mathrm{~g}$, ammonium saltpeter $20 \mathrm{~g}$ and potassium salt $18 \mathrm{~g} / \mathrm{m}^{2}$. Such fertilizers can be used as nitro-amino-phosphate $30-50 \mathrm{~g} / \mathrm{m}^{2}$. It is good to crush down the soil substrate into small lumps and make furrows every $50 \mathrm{~mm}$. It is best to sow seeds processed with solutions of microelements such as cupric sulphate, potassium permanganate or boron acid in concentration of $1 \%$ or $2 \%$ during $6-8$ hours. The norm of seeds sowing is $1.5-2.0 \mathrm{~g} / \mathrm{m}^{2}$. The seed germination power is increased after processing with microelements, the seeding develops better, the herb length and root system are increased and the number of leaves and circumference of the root collar are increased as well. The liquid complex humine fertilizer on the base of Zakarpatian lignite, 20-30 of solution per $10 \mathrm{~L}$ of water is used for watering seedings together without root fertilization, with this procedure taking place 2-3 times during the growth of seedings. Seeds are sowed at a depth of no more than one $\mathrm{cm}$, and covered with soil mixture or sand. Under favourable conditions shoots appear in 10-15 days. When the first true leaves appear, thinning should be performed so the distance between the plants is $40-50 \mathrm{~mm}$. On the $30-40$ th days of sowing they are planted in wide rows with living space of $0.7-0.3 \mathrm{~m}$ between the rows. Dense planting reduces quality of the raw material and seed productivity are reduced. The ground is prepared depending on the previously cultivated plants. If the precursors were cereal crops, then right after harvesting the stubbles at $10-12 \mathrm{~cm}$ depth should be removed and after the weeds are removed the field should be tilled. A total of 80 $100 \mathrm{~kg}$ of nitrogen, $100-120 \mathrm{~kg}$ of phosphorus and $60-80 \mathrm{~kg}$ of potassium is added under the crop or during disking. Before sowing, the soil should be loosened to small particles.

Into the open soil, the seeds can be sown in spring and autumn. In the conditions of the lowland zone of Transcarpathian region sowing in autumn is best carried out in September-October. For sowing, mainly fresh harvested seeds are used or seeds stored for no more than two years, and after the analysis of sprouting has been made. Before sowing the seeds are processed by stimulators of growth or microelements. Processing with humin fertilizers should be made in proportion of $30 \mathrm{~g}$ per 
one liter of water, keeping the seeds in it over 6-8 hours. After this the seeds are dried till friable condition. For sowing large plots, sowing machines of $\mathrm{CKON}-4$ type or $\mathrm{CO}-4$ types are used. Sowing of a small plot is performed manually, making distances between the rows $0.7 \mathrm{~m}$; the norm of sowing is $3-4 \mathrm{~kg}$ seeds/ha, the depth of sowing was down to $10 \mathrm{~mm}$.

During the first year of vegetation, balm grows slowly, therefore over this period the plant requires particular care and watering (if needed), but it is important not to allow it to be overgrown with weeds. During the vegetation, 2-3 interrow weedings should be performed. In the second and the following years, it is reasonable to make extra fertilization with $60-90 \mathrm{~kg}$ of active substance of NPK fertilizer. For our conditions these norms are optimal and higher norms do not cover the expense. Complex fertilizer should be applied during the two periods - the first one in spring during the restoration of vegetation and the second after the first harvesting. Herbs of balm are not damaged by pests or diseases, but they could fall in waterlogged places. While growing lemon balm increasingly occupies the area. The plant density was $752 \pm 83$ individuals $/ 100 \mathrm{~m}^{2}$ with total of $2.320 \pm 355$ seedlings $/ 100 \mathrm{~m}^{2}$ in 2014 .

The raw material for sale is above-ground biomass of balm, harvested before the appearance of the flower buds. At this term, it is reasonable to pay special attention because composition changes into worse side. The first cutting is made at the beginning of June, the second one - in late July or in early August. If the climatic and weather conditions are favourable, a third harvest is possible. The yield of green mass from the first harvest ranges from $500-800 \mathrm{~kg} / \mathrm{ha}$ and $1.500-1.900 \mathrm{~kg} / \mathrm{ha}$ from the second. In the yield structure, stems compose $35-45 \%$ and leaves $55-65 \%$. Raw material is dried in dark and well ventilated buildings (Table 1). In our experimental cultivation, the total dry biomass yield was $3.346 \pm 252 \mathrm{~kg} / \mathrm{ha}$ in the first year and $3.388 \pm 171 \mathrm{~kg} / \mathrm{ha}$ in the second year. The seed productivity was $300-330 \mathrm{~kg} / \mathrm{ha}$, the seed weight per 1000 was $0.7-0.8 \mathrm{~g}$.

Light yellow or colourless pure essential oils were obtained from $10 \mathrm{~g}$ of dry herb sample. Yield ranged $0.05-0.12 \%(\mathrm{v} / \mathrm{w})$ on a dry weight basis. On the other hand, fresh leaves contained about $0.10 \%$ volatile oil (Small, 1997). The results during the first and second cutting of balm herbs showed that the essential oil content varied greatly withing the range $0.12-0.25 \%(0.048-0.100 \mathrm{~g} /$ plant $)$ (Khalid \& Ahmed, 2011). The biochemical composition of the essential oil had improved by the second harvest; these results coincide with results of studies on other essential oil bearing plants (Hendawy \& Khalid, 2005).
Table 1

Quantitative changes of dry biomass $\left(\mathrm{kg} / 100 \mathrm{~m}^{2}\right)$ of balm during two years of cultivation

\begin{tabular}{lcc}
\hline \multicolumn{1}{c}{ Component of dry biomass } & First year & Second year \\
\hline Underground biomass - roots & $10.82 \pm 0.81$ & $12.47 \pm 0.45$ \\
Total overground biomass & $33.46 \pm 2.52$ & $33.88 \pm 1.71$ \\
Overground biomass - stems & $16.61 \pm 3.48$ & $19.58 \pm 2.73$ \\
Overground biomass - leaves & $16.85 \pm 1.53$ & $18.30 \pm 0.79$ \\
Ration of underground /over ground biomass & $1: 3.09$ & $1: 3.04$ \\
\hline
\end{tabular}

Composition of essential oil from lemon balm determines its aromatherapy effects. The most relevant component is $\alpha$-citrale (geranial), content of which depends on the chemotype of the selected plant, which was the variety Citronella (Table 2, Fig. 1).

\section{Table 2}

Comparison of the qualitative and quantitative characteristics of lemom balm essential oils from Ukraine $(x \pm S D, n=3)$

\begin{tabular}{lccr}
\hline \multicolumn{1}{c}{ Component, } & rt, & Ukraine & \multicolumn{1}{c}{ Slovakia } \\
\cline { 3 - 4 } \% of essential oil & min** & variety Citronella & variety Citra \\
\hline D-limonene & 15.2 & $1.70 \pm 0.10$ & $0.55 \pm 0.10$ \\
citronellal & 23.2 & $9.34 \pm 0.55$ & $16.00 \pm 2.04$ \\
methyl citronellate & 25.2 & $1.30 \pm 0.15$ & $0.80 \pm 0.02$ \\
$\beta$-caryophyllene & 26.7 & $0.62 \pm 0.03$ & $9.50 \pm 2.05$ \\
$\beta$-citrale (neral) & 28.4 & $29.90 \pm 2.00$ & $16.00 \pm 1.02$ \\
germacrene D & 29.4 & $0.61 \pm 0.02$ & $0.21 \pm 0.01$ \\
$\alpha$-citrale (geranial) & 29.6 & $44.34 \pm 3.55$ & $18.00 \pm 3.03$ \\
geranyl acetate & 29.8 & $2.98 \pm 0.50$ & $1.41 \pm 0.12$ \\
caryophyllene oxide & 35.7 & $2.70 \pm 0.32$ & $1.85 \pm 0.41$ \\
\hline
\end{tabular}

Note: $*$ - data are expressed as area $\%$ on the total area of the identified peaks; ** - retention times.

Rosmarinic acid is a natural polyphenolic compound and was first discovered in 1958 by the Italian scientists M. L. Scarpatti and G. Oriente (Friedman, 2015). The qualitative and quantitative compositions of the main aromatic and polyphenolic constituents were examined and compared in the leaves of lemon of two years cultivation. The results demonstrated total hydroxycinnamic compounds equaling $6.2 \pm 0.5 \%$, contents of rosmarinic acid $-1.4 \pm 0.1 \%$ (in 2010) and $1.7 \pm 0.1 \%$ (in 2014, Fig. 1) and total flavonoid compounds $-0.5 \%$.

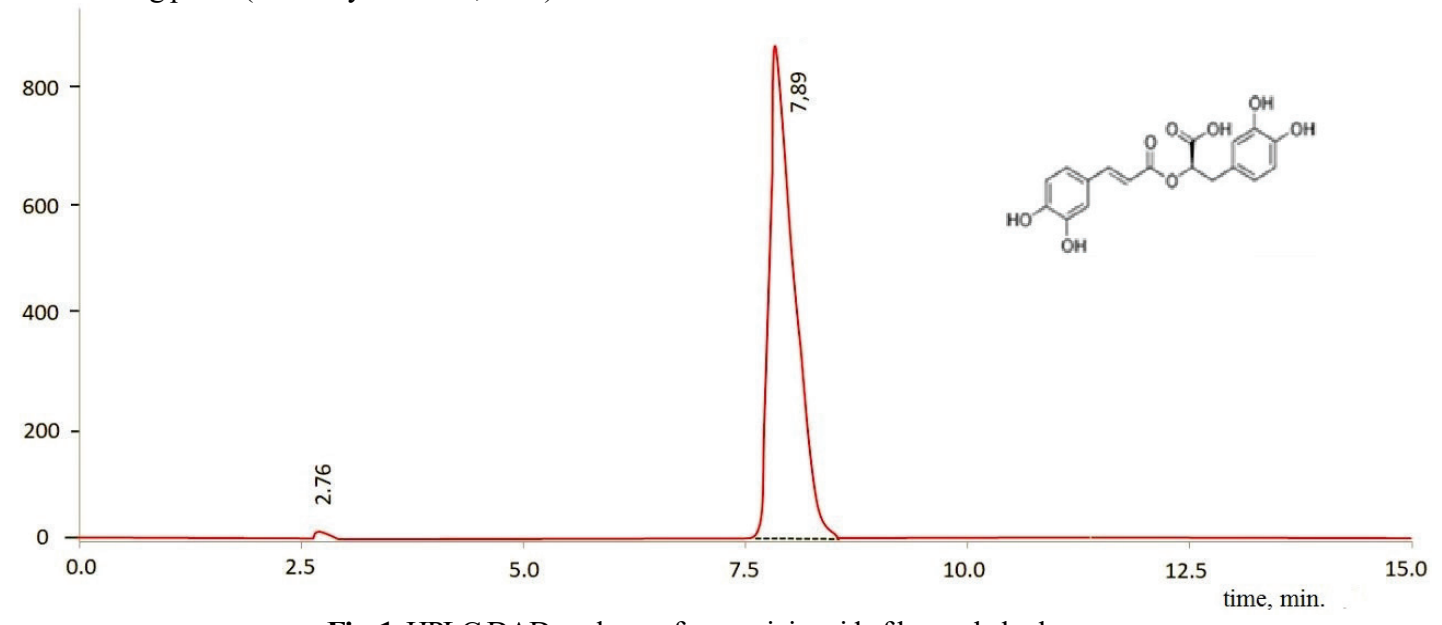

Fig. 1. HPLC DAD analyses of rosmarinic acid of lemon balm leaves

Antimicrobial activity of the oil was tested against bacterial and fungi strains responsible for nosocomial infections: S. aureus, E. coli, E. faecalis, S. pyogenes, C. albicans, C. glabrata. Antibacterial effect of the oil showed low activity against all bacterial strains tested but high antimitotic effect (Table 3).

\section{Discussion}

Balm essential oil can contains up to $40-44 \%$ of $\alpha$-citrale (geranial). Therefore, this natural substance is an aroma compound used in perfumery for its citrus aroma. Citralis also used as a flavouring and for increasing the odour of the essential oil. It also has strong antimicrobial properties and pheromone effects on insects. Citralis is used in the synthesis of vitamin A, ionone, and methyl ionone, to mask the smell of smoke (Burdock, 2009). Among the next constituents, the active are $\beta$ citrale / neral $(29.9 \pm 2.0 \%)$, citronellal $(9.3 \pm 0.5 \%)$, geranyl acetate ( $2.9 \pm 0.5 \%)$, caryophyllene oxide $(2.7 \pm 0.3 \%)$, D-limonene $(1.7 \pm 0.1 \%)$, methyl citronellate $(1.3 \pm 0.1 \%)$ and less than $1 \%$ content is $\beta$-caryophyllene, germacrene D etc. The composition of essential oils from several varieties of peppermint Melissa is different, and the same tendency can be observed for Citra variety cultivated in parallel field in Eastern Slovakia (Table 1). 
The most famous cultivars such as Citra and Citronella are cultivated in Presov (Eastern Slovakia). Their lemon balm oil composition can be characterized by the following compound: $\alpha$-citrale $(26.5 \%), \beta$-citrale $(17.5 \%)$, citronellal $(16.5 \%)$ and $\beta$-caryophyllene $(11.7 \%)$ respectively $\beta$-caryophyllene $(23.3 \%)$, caryophyllene oxide $(18.4 \%), \alpha$-citrale $(10.6 \%)$ and $\beta$-citrale (7.2\%) (Fejér \& Grul'ová, 2017). GC/MS analysis of herbage essential oil from lemon balm grown in Turkey revealed the following main components: citronellal (36.6\% to $43.7 \%)$, citral (10.1\% to $17.4 \%)$, thymol $(0.4 \%$ to $11.9 \%)$ and $\beta$-caryophyllene $(5.9 \%$ to $7.2 \%)$ (Cosge et al., 2009).

Table 3

Antimicrobial activities of the balm essential oils against typical and clinical strains, zones of inhibition $(\mathrm{mm}, \mathrm{x} \pm \mathrm{SD}, \mathrm{n}=3)$

\begin{tabular}{lc}
\hline \multicolumn{1}{c}{ Test-culture } & Balm essential oil \\
\hline S. aureus ATCC 25923 & $9.33 \pm 0.58^{\mathrm{d}}$ \\
S. aureus (clinic) & $9.17 \pm 0.76^{\mathrm{d}}$ \\
E. coli ATCC 25922 & $8.50 \pm 0.50^{\text {cd }}$ \\
E. coli (clinic) & $0.00 \pm 0.00$ \\
E. faecalis ATCC 29212 & $10.33 \pm 0.58^{\mathrm{c}}$ \\
S. pyogenes ATCC 19615 & $9.50 \pm 0.50^{\mathrm{d}}$ \\
S. pyogenes (clinic) & $9.00 \pm 0.35^{\mathrm{d}}$ \\
C. albicans ATCC 885-653 & $14.33 \pm 0.58^{\mathrm{b}}$ \\
C. albicans (clinic) & $14.00 \pm 0.33^{\mathrm{b}}$ \\
C. glabrata (clinic) & $19.33 \pm 0.58^{\mathrm{a}}$ \\
\hline
\end{tabular}

Note: data in the column followed by different letters are significantly different at $\mathrm{P}<0.05$ according to Tukey's HSD test.

Nurzyńska-Wierdak et al. (2014) determined presence of 106 compounds, representing $100 \%$ of the oil constituents, using GC-MS and GC-FID. The predominant components were geranial $(45.2 \%$ and $45.1 \%)$ and neral $(32.8 \%$ and $33.8 \%)$. However, the age of lemon balm plants affected the concentration of other constituents and the proportions of the following compounds were the subject to especially high fluctuations: citronellal $(8.7 \%$ and $0.4 \%)$, geraniol (trace amounts and $0.6 \%$ ), and geranyl acetate $(0.5 \%$ and $3.0 \%)$, as well as isogeranial, Ecaryophyllene, caryophyllene oxide, germacrene D and carvacrol among others.

The anti-inflammatory effect of rosmarinic acid is well documentted. The 2011 study is one of many examples where the inflammation was reduced (Gamaro et al., 2011). The use of this caffeic acid ester was also studied in the 2014 study - on two mice used in the test the supplementation with rosmarinic acid demonstrated anti-inflammatory effect against acute and chronic inflammation resulting from injury. The study suggests that the natural substance has potential for the treatment of pain and inflammation (Boonyarikpunchai et al., 2014). In a study publicshed in 2015, rosmarinic acid has shown effectiveness in reducing the inflammation resulting from injury by modulation of the NF- $\mathrm{kB}$ inflammatory response in rats (Rocha et al., 2015).

In respect to the qualitative-quantitative analyses of lemon balm essential oils originating from Egypt, Serbia and Poland, which were made in the past years, the same sufficient parameters were confirmed (Patora et al., 2003; Mimica-Dukic et al., 2004; Meftahizade et al., 2010). Essential oils in the context of the constantly growing trend towards the formation of antibiotic resistance are promising agents of action against bacteria and microscopic fungi that belong to the transient microbiota of the human organism (Salamon et al., 2017). The reasons for their use are their antimicrobial activity, high antioxidant, aromatic, anti-inflammatory properties. At the same time essential oils cause no disbalance in microbial conenoses of the human body, they are natural preservatives and have a multi-directional positive effect on a number of organs and the systems of the body (Kryvtsova et al., 2017; Kryvtsova et al., 2018; Salamon et al., 2018).

\section{Conclusion}

Thus, the studies have shown that Melissa officinalis L. variety Citronella grown in conditions of Western Ukraine is characterized by biochemical composition and antimicrobial activity that corresponds to the world analogues. Low antibacterial and high antimycotic activity of essential oils was established, and this determines the prospects for fur- ther research and development of cosmetic and hygienic agents for the prevention of mycoses.

\section{References}

Babulka, P. (2005). La mélisse (Melissa officinalis L.). Phytotherapie, 3(3), 114-117. Balouiri, M., Sadiki, M., \& Ibnsouda, S. K. (2016). Methods for in vitro evaluating antimicrobial activity: A review. Journal of Pharmaceutical Analysis, 6(2), 71-79.

Boonyarikpunchai, W., Sukrong, S., \& Towiwat, P. (2014). Antinociceptive and anti-inflammatory effects of rosmarinic acid isolated from Thunbergia laurifolia Lindl. Pharmacology Biochemistry and Behavior, 124(1), 67-73.

Burdock, G. A. (2009). Fenaroli's handbook of flavor ingredients. 6th Edition, CRC Press, Boca Raton.

Cosge, B., Ipek, A., \& Gurbuz, B. (2009). GC/MS analysis of herbage essential oil from lemon balms (Melissa officinalis L.) grown in Turkey. Joumal of Applied Biological Sciences, 3(2), 149-152.

Couladis, M., \& Koutsaviti, A. (2017). Chemical composition of the essential oils of Salvia officinalis, S. fruticosa, Melissa officinalis, and their infusions. Ratarstvo i Povrtarstvo, 54(1), 36-41.

De Sousa, A. C., Gattass, C. R., Alviano, D. S., Alviano, C. S., Blank, A. F., \& Alves, P. B. (2004). Melissa officinalisa L. essential oil: Antitumoral and antioxidant activities. Journal of Pharmacy and Pharmacology, 56(5), 677-681.

Fejér, J., \& Grul'ová, D. (2017). Vplyv exogennych faktorov na tvorbu sekundarnych metabolitov medovky lekarskej (Melissa officinalis L.) [The influence of exogenous factors on the formation of secondary metabolites of lemon balm]. Folia Oecologica, 9(2), 70-79 (in Slovak).

Friedman, T. (2015). The effect of rosmarinic acid on immunological and neurological systems: A basic science and clinical review. Journal of Restorative Medicine, 4(1), 50-59.

Gamaro, G. D., Suyenaga, E., Borsoi, M., Lermen, J., Pereira, P., \& Ardenghi, P. (2011). Effect of rosmarinic and caffeic acids on inflammatory and nociception process in rats. International Scholarly Research Notices Pharmacology, 2011, article ID 451682.

Gurčík, L., Dúbravská, R., \& Miklovičová, J. (2012). Economics of the cultivation of Salvia officinalis and Melissa officinalis. Agricultural Economics (Zemědělská Ekonomika), 51(8), 348-356.

Helmy, S. (2006). Antioxidative properties and antimicrobial activity of different aromatic extracts of Melissa officinalis L. Arab Universities Journal of Agricultural Sciences, 14(1), 299-316.

Hendawy, S. F., \& Khalid, K. A. (2005). Response of sage (Salvia officinalis L.) plants to zinc application under different salinity levels. Journal of Applied Sciences Research, 1(2), 147-155.

Ieri, F., Cecchi, L., Vignolini, P., Belcaro, M. F., \& Romani, A. (2017). HPLC/DAD, GC/MS and GC/GC/TOF analysis of lemon balm (Melissa officinalis L.) samples as standardized raw material for food and nutraceutical uses. Advances Horticulturae Sciences, 31(2), 141-147.

Khalid, K. A., \& Ahmed, A. M. A. (2011). Effect of harvest time on the lemom balm essential oils. Acta Horticulturae, 925, 237-242.

Kryvtsova, M. V., Kohuch, T. T., Salamon, I., \& Spivak, M. J. (2018). Antimicrobial activity of some essential oils on Candida genus clinical isolates. Mikrobiolohichnyi Zhurnal, 80(4), 3-12.

Kryvtsova, M. V., Kostenko, Y. Y., \& Salamon, I. (2018). Compositions of essential oils with antimicrobial properties against isolates from oral cavities of patients with inflammatory diseases of the periodontium. Regulatory Mechanisms in Biosystems, 9(4), 491-494.

Lust, J. (2014). The most complete catalog of the herbs ever published. The herb book. Dover Publication, Mineola, New York.

Macura, R., Michalczyk, M., \& Banaś, J. (2011). Effect of essential oils of coriander (Coriandrum sativum L.) and lemon balm (Melissa officinalis L.) on quality of stored ground veal. Zywnosc Nauka Technologia Jakosc(Poland), 18(4), $127-137$.

Murarikova, A., Kaffkova, K., Raab, S., \& Neugebauerova, J. (2015) Evaluation of content of phenolics in Salvia species cultivated in South Moravian Region. Acta Facultatis Pharmaceuticae Universitatis Comenianae, 13(9), 18-22.

Nurzyńska-Wierdak, R., Bogucka-Kocka, A., \& Szymczak, G. (2014). Volatile constituents of Melissa officinalis leaves determined by plant age. Natural Product Communication, 9(5), 703-706.

Ondrejovič, M., Kraic, F., Benkovičová, H., \& Šilhár, S. (2012). Optimisation of antioxidant extraction from lemon balm (Melissa officinalis). Czech Journal of Food Sciences, 30(4), 385-393.

Patora, J., Majda, T., Gora, J., \& Klimek, B. (2003). Variability in the content and composition of essential oil from lemon balm (Melissa officinalis L.) cultivated in Poland. Acta Poloniae Pharmaceutica - Drug Research, 60(5), 395-340.

Queiroz, R. M. de, Takiya, C. M., Guimarães, L. P. T. P., Rocha, G. da G., Alviano, D. S., Blank, A. F., \& Gattass, C. R. (2014). Apoptosis-inducing effects of Melissa officinalis L. essential oil in glioblastoma multiforme cells. Cancer Investigation, 32(6), 226-235. 
Rocha, J., Eduardo-Figueira, M., Barateiro, A., Fernandes, A., Brites, D., Bronze, R \& Fernandes, E. (2015). Anti-inflammatory effect of rosmarinic acid and an extract of Rosmarimus officinalis in rat models of local and systemic inflammation. Basic and Clinical Pharmacology and Toxicology, 116(5), 398-413.

Rostami, H., Kazemi, M., \& Shafiei, S. (2012). Antibacterial activity of Lavandula officinalis and Melissa officinalis against some human pathogenic bacteria. Asian Journal of Biochemistry, 7(3), 133-142.

Safaeian, L., Sajjadi, S., Javanmard, S., Montazeri, H., \& Samani, F. (2016). Protective effect of Melissa officinalis extract against $\mathrm{H}_{2} \mathrm{O}_{2}$-induced oxidative stress in human vascular endothelial cells. Research in Pharmaceutical Sciences, 11(5), 383.

Salamon, I., Kryvtsova, M., Bucko, D., \& Tarawneh, A. (2018). Chemical characterization and antimicrobial activity of some essential oils after their industrial arge-scale distillation. The Journal of Microbiology, Biotechnology and Food Sciences, 8(3), 965-969.

Salamon, I., Kryvtsova, M., Bucko, D., \& Tatawneh, A. (2018). Natural components and antimicrobial activity of some essential oils after their industrial large-scale distillation. "International congress on natural products from plants and co-products to medicaments and Bio-agriculture". Hammamet, Tunisia, 8-10 Novembwer, 2018.

Zazharskyi, V. V., Davydenko, P. O., Kulishenko, O. M., Borovik, I. V., \& Brygadyrenko, V. V. (2019). Antimicrobial activity of ethanol extracts of 50 plant species. Biosystems Diversity, 27(2), in print. 